\title{
Antifungal Properties of Malaysian Tualang Honey and Stingless Bee Propolis against Candida albicans and Cryptococcus neoformans
}

\author{
Aminu Shehu ${ }^{1}$, Salwani Ismail ${ }^{1}$, Mohd Adzim Khalili Rohin ${ }^{2}$, Azian Harun ${ }^{3}$, Aniza Abd Aziz ${ }^{1}$, Mainul Haque ${ }^{1}$ \\ ${ }^{1}$ Faculty of Medicine, Universiti Sultan Zainal Abidin (UniSZA), Medical Campus, Jalan Sultan Mahmud, 20400 Kuala Terengganu, Terengganu, Malaysia \\ ${ }^{2}$ Faculty of Health Sciences, UniSZA, Gong Badak Campus, 21300, Kuala Terengganu, Terengganu, Malaysia. ${ }^{3}$ Department of Medical Microbiology and \\ Parasitology, School of Medical Sciences, Universiti Sains Malaysia, Health Campus, 16150, Kubang Kerian, Kelantan, Malaysia.
}

\begin{tabular}{l}
\hline ARTICLE INFO \\
\hline Article history: \\
Received on: 04/11/2015 \\
Revised on: 11/12/2015 \\
Accepted on: 27/12/2015 \\
Available online: 27/02/2016 \\
\hline Key words: \\
Honey, Propolis, MIC, MFC, \\
phenolic acids, flavonoids.
\end{tabular}

\section{INTRODUCTION}

C. albicans is the most common cause of human candidiasis. It is part of the human normal flora of the skin, mucous membranes, and gastrointestinal tract.

It is commonly responsible for opportunistic infections in immunocompromised patients or patients who are undergoing therapy with broad-spectrum antibiotics or in those with certain physiological disorders (Kourkoumpetis et al., 2010; Sobel, 2007; Nucci et al., 2010). It can cause oropharyngeal candidiasis, invasive candidiasis, and vulvovaginal candidiasis. The selection

\footnotetext{
* Corresponding Author

E-mail: salwani@unisza.edu.my

Tel: +60199394557; Fax: +6096275639
}

\begin{abstract}
Candida albicans and Cryptococcus neoformans can cause life-threatening infections, especially in immunecompromised patients. Treatment with currently available antifungal agents may lead to severe side-effects and emergence of resistant strains. The objective of this study was to evaluate the antifungal properties of MTH and SBP against $C$. albicans and $C$. neoformans. Broth dilution method was used to assess the antifungal properties of the MTH and propolis. Different concentrations of the MTH and propolis $(0.78 \mathrm{mg} / \mathrm{mL}-50.00 \mathrm{mg} / \mathrm{mL})$ in two-fold dilutions were tested against each fungus to determine the Minimum Inhibitory Concentration (MIC) which was done by visual inspection and spectrophotometric $\left(\mathrm{MIC}_{95}\right)$ reading at $620 \mathrm{~nm}$. Minimum Fungicidal Concentration (MFC) was obtained by culturing on Sabouraud Dextrose Agar. Total phenolic acids and flavonoids contents were also determined by Folin-Ciocalteu and colorimetric assay respectively. The MICs of the MTH against $C$. albicans and $C$. neoformans by visual inspection were $6.25 \mathrm{mg} / \mathrm{mL}$ and $1.56 \mathrm{mg} / \mathrm{mL}$ respectively, meanwhile $6.25 \mathrm{mg} / \mathrm{mL}$ and $3.13 \mathrm{mg} / \mathrm{mL}$ by spectrophotometric reading. The MFCs of the MTH against $C$. albicans and C. neoformans were $12.50 \mathrm{mg} / \mathrm{mL}$ and $6.25 \mathrm{mg} / \mathrm{mL}$ respectively. The MICs of SBP against $C$. albicans and $C$. neoformans by visual inspection were both $1.56 \mathrm{mg} / \mathrm{mL}$ whereas spectrophotometric reading recorded MICs of $3.13 \mathrm{mg} / \mathrm{mL}$ and $1.56 \mathrm{mg} / \mathrm{mL}$ respectively. The MFCs of SBP against $C$. albicans was $6.25 \mathrm{mg} / \mathrm{mL}$ and $3.13 \mathrm{mg} / \mathrm{mL}$ for C. neoformans. The total phenolic acids and flavonoids contents of MTH were $275.6 \mathrm{mg}$ gallic acid $/ \mathrm{kg}$ and $71.8 \mathrm{mg}$ quercetin/ $\mathrm{kg}$ respectively whereas for SBP, the phenolic acids content was $1754.2 \mathrm{mg}$ gallic acid/kg and the flavonoids content was $82.6 \mathrm{mg}$ quercetin $/ \mathrm{kg}$. MTH and SBP exhibited significant antifungal activities against $C$. albicans and $C$. neoformans. Their antifungal activities might be attributed to the high phenolic acids and flavonoids. This result suggests that MTH and SBP could potentially be used as alternative therapeutic agents against these fungi.
\end{abstract}

of antifungal treatment for candidiasis usually depends on the severity of the infection and the parts of the body that are affected. The antifungal agents that are commonly used for candidiasis include topical nystatin, ketoconazole, amphotericin B, flucytosine, fluconazole and caspofungin (Nucci et al., 2010; Pappas et al., 2009). C. neoformans is a fungus that lives in the environment throughout the world. Infection with this fungus is called cryptococcosis. Cryptococcosis usually affects the lungs or the central nervous system. Most of $C$. neoformans infections occur in immunocompromised patients particularly those who have advanced HIV/AIDS (Alvarez et al., 2009; Buchanan and Murphy, 1998). Similar to candidiasis, cryptococcosis treatment also depends on the severity of the infection and the parts of the body that are affected. 
Commonly used antifungal agents for cryptococcosis include amphotericin B, flucytosine and fluconazole (Mirza et al., 2003). The common side effects of amphotericin B and flucytosine include diarrhea, headache, indigestion, loss of appetite, nausea, vomiting and abdominal pain. Besides that, these drugs also can cause renal toxicity.

Likewise fluconazole, it can cause diarrhea, difficulty in swallowing, dizziness, tachycardia, fever, lethargy, headache, allergic reaction, sudden loss of consciousness, swollen glands and unusual bleeding or bruising. Resistance to antifungal drugs, specifically azoles such as fluconazole in $C$. albicans and $C$. neoformans has become an increasing problem especially in HIVinfected individuals (Rossi, 2012; Shin et al., 2007). Honey and propolis are natural products known to have antimicrobial properties.

MTH is produced by the rock bee (Apis dorsata), which builds hives high up in the branches of Tualang tree (Kompassia excelsa), that is found mainly in tropical rain forests, and can reach up to 250 feet in height (Rahim et al., 2011). In Malaysia, the trees are plentiful in the North-Eastern region in the state of Kedah (Rahim et al., 2011).

The antimicrobial properties of MTH are unique to its acidic $\mathrm{pH}$, high osmolarity, the release of hydrogen peroxide and plant derived non-peroxide factors (phenolic acids and flavonoids), which inhibit microbial growth (Molan, 1998; George and Cutting, 2007; Franchini et al., 2007). Most types of honey generate hydrogen peroxide when diluted because of the activation of the enzymes glucose oxidase, which oxidized glucose to gluconic acid and hydrogen peroxide (Bang et al., 2003).

Hydrogen peroxide contributes significantly toward the antimicrobial activity of honey, and its concentrations also vary from one honey to another due to differences in geographical origin (Bang et al., 2003). Stingless bees are a group of eusocial insects belonging to five different genera, including Trigona, Melipona, Meliponula, Dectylurina and Lestrimelitta, which play a significant role in pollination (Heard, 1999). All these genera also produce propolis; a resinous mixture that honey bees (Trigona thoracica) collect from tree buds, sap flows, or other botanical sources, then mix with beeswax, salivary enzymes and other compounds of bee metabolism (Burdock, 1998; Bankova et al., 2000). Honeybees used propolis to protect the hive, sealing openings and cracks, making the internal wall as smooth as possible, repair the combs and making the entrance of the hive easier to defend (Burdock, 1998; Bankova et al., 2000; Melliou et al., 2007).

Previous studies showed that various compounds like phenolics and flavonoids present in honey and propolis are responsible for their antifungal activity by affecting the permeability of the cytoplasmic membrane, which lead to the total leakage of the cellular constituents such as nucleic acids, proteins and inorganic ions such as phosphate and potassium, leading to complete cell death (Farnesis et al., 2009; Montero and Mori, 2012). To date, there are no extensive studies reported on the antifungal properties of MTH and SBP of Trigona thoracica species against these two fungi. The objective of this study was to evaluate the antifungal properties of MTH and SBP against $C$. albicans and $C$. neoformans.

\section{MATERIALS AND METHODS}

\section{Honey Sample}

The honey sample used in this study was Tualang honey (AgroMas $^{\circledR}$ ). It was supplied by the Federal Agricultural and Marketing Authority (FAMA) of Malaysia. Prior to analysis, the honey sample was subjected to gamma irradiation at a dose of 25 $\mathrm{kGy}$ and subsequently stored at room temperature.

\section{Propolis Sample and Propolis Extract Preparation}

Propolis produced by stingless bees of Trigona thoracica species was supplied by the Min House Camp in Kubang Kerian, Kelantan, Malaysia. The SBP sample was kept at $-20{ }^{\circ} \mathrm{C}$ for 3 days. The sample was crushed using mortar and pestle and then mixed with sterile distilled water (1 g of SBP per $10 \mathrm{~mL}$ of distilled water).

The mixture was heated on a hot plate at $40{ }^{\circ} \mathrm{C}$ until it completely dissolved. It was then allowed to cool to room temperature and vortexed for 15 minutes and filtered through a filter paper (Whatman number 6). The obtained filtrate was evaporated at $40{ }^{\circ} \mathrm{C}$ using a hot oven and then finally stored at $4{ }^{\circ} \mathrm{C}$ in the dark until it was tested for antifungal activity (Siqueira et al., 2009).

\section{Test Organisms}

Two types of pathogenic fungi were tested in this study. They are C. albicans (ATCC 25987) and C. neoformans (a local clinical isolate obtained from Microbiology and Parasitology Laboratory, School of Medical Sciences, Health Campus, Universiti Sains Malaysia, Kubang Kerian, Kelantan, Malaysia. The local clinical isolate was correctly identified $(99.9 \%)$ as C. neoformans by using bioMerieux ${ }^{\mathrm{TM}}$ API $20 \mathrm{C}$ AUX.

\section{Inoculum Preparation}

The inocula were prepared by picking 3-5 morphologically identical colonies from overnight growth with a sterile inoculating wire loop. The colonies were then suspended in 4-5 mL of sterile Mueller-Hinton broth (MHB) and subsequently incubated at $35-37{ }^{\circ} \mathrm{C}$ for 24 hours. The optical density (OD) of the actively growing culture was adjusted with sterile MHB to matches 0.5 McFarland standard (1-5 x $\left.10^{6} \mathrm{CFU} / \mathrm{mL}\right)$ (CLSI, 2009).

\section{Minimum Inhibitory Concentration (MIC)}

The MICs of MTH and SBP were determined with some minor modifications of following studies (Vollekova et al., 2001; Usman et al., 2007; Tan et al., 2009). A stock solution of 50 $\mathrm{mg} / \mathrm{mL}$ of MTH was prepared by dissolving $5 \mathrm{~g}$ of MTH in 100 $\mathrm{mL}$ of Dimethyl sulfoxide (DMSO). Two-fold serial dilutions were made to obtained MTH concentrations of 50.00, 25.00, 
$12.50,6.25,3.13,1.56$ and $0.78 \mathrm{mg} / \mathrm{mL}$. Similarly, a stock solution of SBP $(50 \mathrm{mg} / \mathrm{mL})$ was also prepared by dissolving $5 \mathrm{~g}$ of SBP in $100 \mathrm{~mL}$ of DMSO. Different concentrations of SBP was obtained by Two-fold serial dilutions (50.00, 25.00, 12.50, 6.25, 3.13, 1.56 and $0.78 \mathrm{mg} / \mathrm{mL}$ ).

There were three control tubes for each assay; tubes containing broth only (negative control), tubes containing broth and inoculum only without MTH or SBP (positive control) and tubes containing broth and MTH only or broth and SBP only without inoculum (corresponding negative control) respectively. Two hundred micro litter $(200 \mu \mathrm{L})$ suspensions of the organism were inoculated into all the tubes except two control tubes (negative control and corresponding negative control). All the test tubes were stoppered with aluminum foil and then incubated at $37{ }^{\circ} \mathrm{C}$ for 48 hours. The growth of the organisms was observed by visual inspection and by measuring the OD at $620 \mathrm{~nm}$ using a spectrophotometer. The OD was measured immediately after visual observation.

The lowest concentration of MTH or SBP that inhibited the growth of each microorganism, as detected by the lack of visible turbidity compared to a corresponding negative control was recorded as visual MIC. All tests were performed in triplicate and were repeated five times to ensure the reproducibility of the results. $\mathrm{MIC}_{95}$ is defined as the concentration of $\mathrm{MTH}$ or SBP required to inhibit the fungal growth by $95 \%$. The $\mathrm{MIC}_{95}$ was obtained from the growth inhibition graph. The growth inhibition percentage was calculated using the formula: Percent inhibition = [1 - (OD test tube - OD corresponding negative control tube)/ (OD viability control tube - OD broth only tube)] $\times 100 \%$. The minimum and maximum values were $0 \%$ and $100 \%$, respectively.

\section{Minimum Fungicidal Concentration (MFC)}

The MFC of MTH or SBP was determined by taking a loop full of the culture medium from each test tube (from the broth MIC assay) that showed $80 \%$ and $100 \%$ of growth inhibition and sub-culturing on fresh Sabouroud Dextrose Agar (SDA) plates, then incubated at $37{ }^{\circ} \mathrm{C}$ for 48 hours. The MFC is the least concentration showing no growth on the SDA plates (CLSI, 2009).

\section{Total Phenolic Acids Content of MTH and SBP}

The total phenolic acids contents of MTH or SBP were determined by the Folin-Ciocalteu's reagent (Beretta et al., 2005; Singleton et al., 1999) with some minor modifications. Five hundred milligram (500 mg) of MTH and $500 \mathrm{mg}$ SBP were mixed with $5 \mathrm{~mL}$ distilled water respectively and was vortex mixed for 5 minutes.

These solutions $(0.5 \mathrm{~mL})$ were then mixed with $2.5 \mathrm{~mL}$ of Folin-Ciocalteu reagents and allowed to stand for 5 minutes, and $2 \mathrm{~mL}$ of $75 \mathrm{~g} / \mathrm{l}$ sodium carbonate $\left(\mathrm{Na}_{2} \mathrm{CO}_{3}\right)$ was then added. After being incubated at room temperature for 30 minutes, the absorbance of the reaction mixture was measured at $760 \mathrm{~nm}$ against a blank. Gallic acid $(10-250 \mu \mathrm{g} / \mathrm{mL})$ was used as a standard to produce the calibration curve. The mean of three readings was used, and the total phenolic acids content was expressed in mg of Gallic acid equivalents (GAE)/kg MTH or SBP.

\section{Total Flavonoids Content of MTH and SBP}

The total flavonoids contents of MTH or SBP were measured using the colorimetric assay (Zhishen et al., 1999; Arvouet-Grand et al., 1994) with modifications. $1 \mathrm{~mL}$ of MTH (20 $\mathrm{mg} / \mathrm{mL})$ and $1 \mathrm{~mL}$ of SBP $(20 \mathrm{mg} / \mathrm{mL})$ was mixed with $1 \mathrm{~mL}$ of $2 \%$ aluminum trichloride $\left(\mathrm{AlCl}_{3}\right)$ (Labosi, Paris, France), followed by the addition of $1 \mathrm{~mL}$ of potassium acetate. After 6 minutes, the volume was then increased to $5 \mathrm{~mL}$ by the addition of $2 \mathrm{~mL}$ distilled water.

The mixture was vigorously shaken to ensure adequate mixing, and the absorbance was read at $415 \mathrm{~nm}$ after 40 -minutes incubation in a dark. The total flavonoids content was determined using a standard curve with quercetin as the standard. The mean of three readings was used and expressed as $\mathrm{mg}$ of quercetin equivalents $(\mathrm{QE}) / \mathrm{kg}$ of MTH and SBP.

\section{RESULT AND DISCUSSION}

\section{Visual MIC, $\mathrm{MIC}_{95}$ and MFC Results of MTH against Candida albicans}

The MIC and $\mathrm{MIC}_{95}$ results of MTH, when tested against C. albicans using broth dilution method, were both $6.25 \mathrm{mg} / \mathrm{mL}$. The MFC of the honey was $12.50 \mathrm{mg} / \mathrm{mL}$. The results obtained were summarized in Table 1.

\section{Visual MIC, $\mathrm{MIC}_{95}$ and MFC Results of MTH against Cryptococcus neoformans}

The MIC of MTH by visual inspection was $1.56 \mathrm{mg} / \mathrm{mL}$ whereas the $\mathrm{MIC}_{95}$ was $3.13 \mathrm{mg} / \mathrm{mL}$. The $\mathrm{MFC}$ of the MTH was $6.25 \mathrm{mg} / \mathrm{mL}$. The results obtained were summarised in Table 1.

\section{Visual MIC, $\mathrm{MIC}_{95}$ and MFC Results of SBP against Candida albicans}

The MIC and $\mathrm{MIC}_{95}$ of SBP were $1.56 \mathrm{mg} / \mathrm{mL}$ and 3.13 $\mathrm{mg} / \mathrm{mL}$ respectively. The MFC was $6.25 \mathrm{mg} / \mathrm{mL}$ (Table 1).

\section{Visual MIC, $\mathrm{MIC}_{95}$ and MFC Results of SBP against Cryptococcus neoformans}

The MIC and $\mathrm{MIC}_{95}$ of SBP were both $1.56 \mathrm{mg} / \mathrm{mL}$. The MFC of SBP was found to be $3.13 \mathrm{mg} / \mathrm{mL}$ (Table 1).

\section{Total Phenolic Acids and Flavonoids Contents of MTH}

The MTH had total phenolic acids content of 275.6 $\mathrm{mg} / \mathrm{kg}$ while the total flavonoid content was $71.8 \mathrm{mg} / \mathrm{kg}$ (Table 2).

\section{Total Phenolic acids and Flavonoids Contents of SBP}

The phenolic acids content was found to be 1754.2 $\mathrm{mg} / \mathrm{kg}$ of SBP while the flavonoids content was $82.6 \mathrm{mg} / \mathrm{kg}$ of SBP (Table 2). 
Table 1: MIC, MIC 95 and MFC of MTH and SBP against C. albicans and C. neoformans.

\begin{tabular}{|c|c|c|c|c|c|c|c|c|c|}
\hline \multirow[t]{2}{*}{ Organism } & \multirow[t]{2}{*}{ MTH concentrations $(\mathrm{mg} / \mathrm{mL})$} & \multicolumn{2}{|c|}{$\begin{array}{c}\text { Tube } \\
\text { observation } \\
\end{array}$} & \multicolumn{2}{|c|}{$\begin{array}{c}\text { Visual MIC } \\
(\mathrm{mg} / \mathrm{mL})\end{array}$} & \multicolumn{2}{|c|}{$\begin{array}{c}\mathrm{MIC}_{95} \\
(\mathrm{mg} / \mathrm{mL})\end{array}$} & \multicolumn{2}{|c|}{$\begin{array}{c}\text { MFC } \\
(\mathrm{mg} / \mathrm{mL}) \\
\end{array}$} \\
\hline & & MTH & SBP & MTH & SBP & MTH & SBP & MTH & SBP \\
\hline \multirow{7}{*}{ Candida albicans } & 50.00 & - & - & \multirow{7}{*}{6.25} & \multirow{7}{*}{1.56} & \multirow{7}{*}{6.25} & \multirow{7}{*}{3.13} & \multirow{7}{*}{12.50} & \\
\hline & 25.00 & - & - & & & & & & \\
\hline & 12.50 & - & - & & & & & & \\
\hline & 6.25 & - & - & & & & & & 6.25 \\
\hline & 3.13 & + & - & & & & & & \\
\hline & 1.56 & + & - & & & & & & \\
\hline & 0.78 & + & + & & & & & & \\
\hline \multirow{7}{*}{ Cryptococcus neoformans } & 50.00 & - & - & \multirow{7}{*}{1.56} & \multirow{7}{*}{1.56} & \multirow{7}{*}{3.13} & \multirow{7}{*}{1.56} & \multirow{7}{*}{6.25} & \multirow{7}{*}{3.13} \\
\hline & 25.00 & - & - & & & & & & \\
\hline & 12.50 & - & - & & & & & & \\
\hline & 6.25 & - & - & & & & & & \\
\hline & 3.13 & - & - & & & & & & \\
\hline & 1.56 & - & - & & & & & & \\
\hline & 0.78 & + & + & & & & & & \\
\hline
\end{tabular}

Table 2: Total Phenolic Acids and Flavonoids Contents of MTH and SBP.

\begin{tabular}{|c|c|c|c|}
\hline \multirow{2}{*}{$\mathbf{S} / \mathbf{n}$} & \multirow{2}{*}{ Parameters } & \multicolumn{2}{|c|}{$(\text { Mean } \pm \text { SD })^{*}$} \\
\hline & & МТH & SBP \\
\hline 1 & Total phenolic acids contents (mg gallic acid/kg) & $275.6 \pm 12.5$ & $1754.2 \pm 24.5$ \\
\hline 2 & Total flavonoids contents (mg quercetin/kg) & $71.8 \pm 11.3$ & $82.6 \pm 7.4$ \\
\hline
\end{tabular}

SD = standard deviation; MTH = Malaysian tualang honey; SBP = Stingless bee propolis

*All determinations were carried out in triplicate and the values were expressed as mean \pm SD

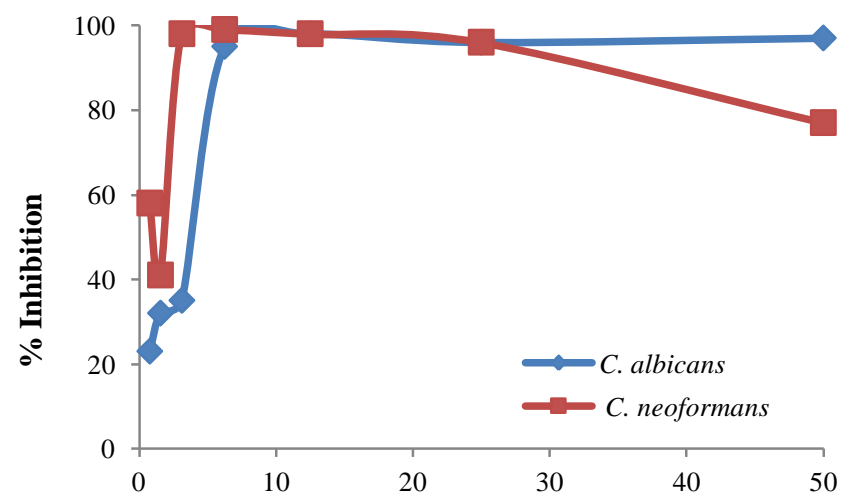

Concentration $(\mathbf{m g} / \mathbf{m L})$

Fig. 1: Growth Inhibition of C. albicans and C. neoformans at Different Concentration of MTH.

Figure 1 and 2 shows the pattern of fungal growth inhibition caused by exposure to different concentrations of MTH and SBP. Fungal growth inhibition started gradually from the lower concentration to the higher concentration of MTH and SBP until it nearly reached $100 \%$ inhibition.

Based on this study, the results showed that both MTH and SPB have antifungal properties against two clinically significant fungi namely $C$. albicans and $C$. neoformans evidenced by Broth dilution method (Kacaniova et al., 2009). In addition, $C$. neoformans is found to be more sensitive to MTH and SBP as compared to $C$. albicans. Moreover, SBP was also demonstrated to be more efficient than the MTH in inhibiting the growth of the

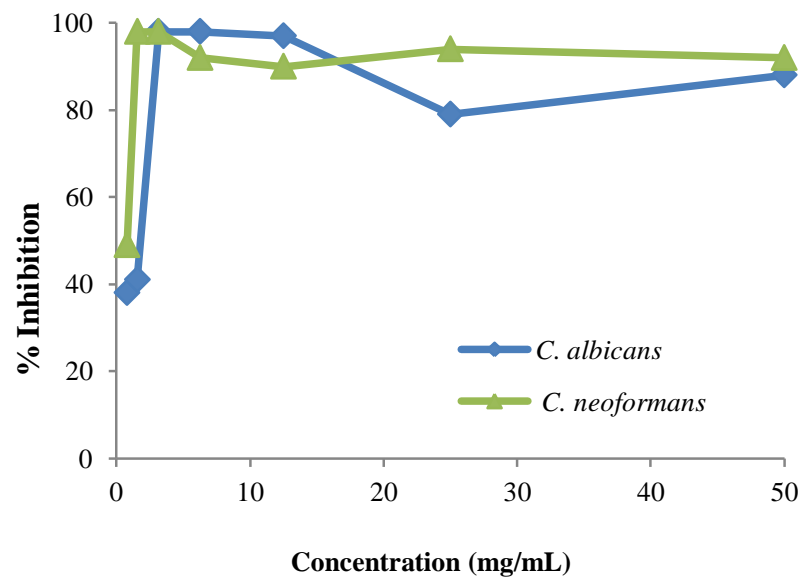

Fig. 2: Growth Inhibition of $C$. albicans and C. neoformans at Different Concentration of SBP.

tested organisms, which is attributed to its higher phenolic acids and flavonoids compound. The visual MIC result of MTH against $C$. neoformans was lower compared to the $C$. albicans. It indicates that $C$. neoformans are more sensitive to MTH compared to $C$. albicans. Similarly, the spectrophotometric readings $\left(\mathrm{MIC}_{95}\right)$ of MTH against $C$. albicans and $C$. neoformans signified more inhibition of the growth of $C$. neoformans compared to $C$. albicans. The MFC result of MTH also revealed higher fungicidal activity against $C$. neoformans than the $C$. albicans.

The outcome of this study was consistent with a recent survey (Koc et al., 2009) on the antifungal activity of four Turkish honey (multifloral, rhododendron, eucalyptus and orange) which 
revealed that all the honey tested had fungistatic and fungicidal activity against $C$. albicans at low concentration of $1.25 \%(\mathrm{~V} / \mathrm{V})$. The in vitro antifungal activity of lavender honey was reported that lavender honey inhibited the growth of $C$. albicans, $C$. neoformans and $C$. krusei at a concentration of $10 \%$ (W/V) (Maria et al., 2011). This is also in agreement with the findings of the current study. In an in vitro study with two types of fungi and 21 bacteria, Medihoney was found to be very effective in inhibiting the growth of $C$. albicans, $C$. neoformans, and all the bacteria. The MIC of Medihoney was ranged from $1.8 \%$ to $10.8 \%$ (V/V) (Wahdan, 1998; Molan, 2001). Nonetheless, there was no similar study conducted previously on the antifungal activity of MTH.

The results of the total phenolic acids and flavonoids contents showed $275.6 \mathrm{mg} / \mathrm{kg}$ as the total phenolic acids contents and $71.8 \mathrm{mg} / \mathrm{kg}$ as total flavonoids contents of MTH. The 275.6 $\mathrm{mg} / \mathrm{kg}$ total phenolic acids contents reported in the present study was in line with that revealed by (Mohamed et al., 2010; Khalil et $a l ., 2010)$, in which both reported the phenolic acids contents of MTH produced by Apis dorsata in their study. The phenolic acids contents published by (Mohamed et al., 2010, Khalil et al., 2010) was $251.7 \mathrm{mg} / \mathrm{kg}$ and 273.46 to $292.34 \mathrm{mg} / \mathrm{kg}$ respectively; their findings were within the range when compared to that of the present study. It has been reported higher phenolic acids content (352.73 $\mathrm{mg} / \mathrm{kg}$ ) of MTH produced by Apis dorsata compared to that of the present study $(275.6 \mathrm{mg} / \mathrm{kg})$, while the flavonoids contents $(65.65 \mathrm{mg} / \mathrm{kg})$ was in agreement with the outcome of this study (Moniruzzaman et al., 2012). Studies conducted with other types of honey was also reported, the total phenolic acids content and flavonoids content of Borneo tropical honey was reported to be $223.20 \mathrm{mg} / \mathrm{kg}$ and $31.89 \mathrm{mg} / \mathrm{kg}$ (Khalil et al., 2010; Bertoncelj et al., 2007) reported the total phenolic acids content of Fir honey (241.4 mg/kg), Spruce honey (217.5 mg/kg) and Forest honey $(233.9 \mathrm{mg} / \mathrm{kg}$ ). Another study revealed the phenolic acids content of Buckwheat honey $(482.2 \mathrm{mg} / \mathrm{kg})$, Honeydew $(255.6 \mathrm{mg} / \mathrm{kg})$ and Chestnut honey (211.2 mg/kg) (Baretta et al., 2005). The total flavonoids contents of Rhododendron honey ranged from 12.76 $\mathrm{mg} / \mathrm{kg}$ to $80.80 \mathrm{mg} / \mathrm{kg}$; this is also in line with findings of the present study. Honey inhibits microbial growth due to its high sugar content (reduced water activity), low $\mathrm{pH}$, the presence of phenolic acids, flavonoids, generation of hydrogen peroxide $\left(\mathrm{H}_{2} \mathrm{O}_{2}\right)$ when diluted and enzymes or other proteinaceous compounds (Shehu et al., 2015). Nevertheless, its antifungal is mainly attributed to the phenolic compounds (Estevinho et al., 2008). Phenolic acids in honey were reported to affect the permeability of the cytoplasmic membrane, which lead to the total leakage of the cellular constituents like nucleic acids, proteins and inorganic ions such as phosphate and potassium, leading to complete cell death (Farnesis et al., 2009; Montero and Mori, 2012). Other research reported that honey from different phytogeographic regions varies in their ability to inhibit the growth of yeasts, suggesting that the botanical origin plays a significant role in influencing the antifungal activity of a particular honey (DeMera and Angert, 2004). Honey can be used to prevent more serious infections and could be incorporated into the therapy of oral and vaginal candidiasis (Irish et al., 2006). Regarding the $\mathrm{SBP}$, the visual MIC result of SBP against $C$. albicans and $C$. neoformans revealed similar sensitivity. $C$. neoformans was found to have lower spectrophotometric readings $\left(\mathrm{MIC}_{95}\right)$ compared to $C$. albicans; this indicates a better growth inhibition at lower concentration. The MFC result of SBP revealed that lower concentrations of SBP are needed to kill the $C$. neoformans compared to $C$. albicans. Presence of phenolic acids and flavonoids such as pinocembrin, morin, rutin, and quercetin in the propolis may also target the cell wall of the $C$. neoformans, affecting its structure (denature proteins, being generally classified as surface active agents), blocking its synthesis and causing cell death (Campos et al., 2009).

The outcome of this study was similar to that of other studies (Kujumgiev et al., 1999; Salmon et al. (2004), which reported the fungicidal activity of SBP against Candida spp. Additionally, the outcome of this present study was consistent with the other study (Kacaniova et al., 2009) which revealed the antifungal activity of Propolis against Candida species. The study (Kacaniova et al., 2009) was purely based on discs diffusion and reported the fungistatic activity of propolis against $C$. albicans $(3.75 \pm 1.77)$. Moreover, reported the fungicidal activity of SBP at a concentration of $1 \mathrm{mg} / \mathrm{ml}$ to $12 \mathrm{mg} / \mathrm{ml}$ against all the tested Candida spp ( $C$. albicans, $C$. tropicalis, $C$. Cruise and $C$. guilliermondii) (Ota et al., 2001). Propolis extract also showed excellent performance in an in vitro test against vaginal yeasts $(C$. albicans, C. glabrata, C. guilliermondii and C. parapsilosis) by inhibiting their growth at a maximal concentration $(393.19 \mu \mathrm{g} / \mathrm{ml})$ (Dalben-date et al., 2010). Moreover, the finding of another study (Oliveira et al., 2006) showed a high activity of Propolis against $C$. albicans and $C$. non-albicans isolated from patient with onychomycoses; this is also in line with the outcome of this study. The results of the present study were also in agreement with the study (Hegazi \& Abed El Hardy, 2000) on the antifungal activity of SBP samples against $C$. albicans, which reported the antifungal activity of Egyptian Propolis ranging from $1320 \mu \mathrm{g} / \mathrm{ml}$ to 3380 $\mu \mathrm{g} / \mathrm{ml}$.

The antifungal activity of SBP can be attributed to the presence of flavonoids, aromatic acids, and esters present in resins (Montero and Mori, 2012; De Carvalho et al., 2007; Sforcin and Bankova, 2011). Quercetin, kaemphterol, galangin, and pinocembrin are among the most efficient flavonoids agents found in the Propolis, which contribute significantly to the fungicidal action of the SBP (Montero and Mori, 2012; De Carvalho et al., 2007; Sforcin and Bankova, 2011). The variation in the antifungal activity of Propolis referred to the differences in the chemical composition of Propolis from one area to another. This variation produced variable synergistic effects of the phenolic compounds (Montero and Mori, 2012; Kujumgiev et al., 1999; Hegazi and Abd El Hady, 2000; Sforcin and Bankova, 2011).

The present study revealed $1754.2 \mathrm{mg} / \mathrm{kg}$ as the total phenolic acid contents and $82.6 \mathrm{mg} / \mathrm{kg}$ as the total flavonoids contents of the SBP. The total phenolic acid contents reported was supported by the findings from the previous studies conducted on 
the SBP of Portugal from two regions Fonda and Bornes (1510 $\mathrm{mg} / \mathrm{kg}-3290 \mathrm{mg} / \mathrm{kg}$ ) [52]. Recently, reported a little bit lower phenolic acid contents $(1500 \mathrm{mg} / \mathrm{kg}$ ) from SBP of Tamilnadu, India (Jayanthi et al., 2014). Moreover, higher phenolic acid contents were also found in SBP of Chinese samples from Hebei (3020 mg/kg) (Ahn et al., 2007) and Hubei (2990 mg/kg) (Kumazawa et al., 2004) and Korean Propolis from Yeosu (2127 $\mathrm{mg} / \mathrm{kg}$ ). Another study reported that the antioxidant activity of SBP and revealed the total flavonoids contents $(60 \mathrm{mg} / \mathrm{kg})$ was lower when compared with the present study (Jayanthi et al., 2014).

Generally, the variation in the phenolic acids contents and flavonoids contents of honey and Propolis is directly related to their complex chemical composition, which can vary according to the season, a region of plant resin collection and bee species (Silva et al., 2008).

\section{CONCLUSION}

MTH produced by honey bees of the species Apis dorsata and SBP produced by Trigona thoracica species exhibited significant antifungal activities which are not only fungistatic but also fungicidal against both $C$. albicans and $C$. neoformans. SBP had higher antifungal properties against the tested organisms compared to MTH; this might be attributed to the high phenolic acids and flavonoids content presented in the SBP. This result suggests that MTH and SBP could potentially be used as alternative therapeutic agents against these two common fungi.

\section{ACKNOWLEDGEMENTS}

I am very grateful to the Kano State Government of Nigeria for their financial support in the smooth running of this study. Likewise, my appreciation goes to Prof. Dr. Siti Amrah bt Sulaiman, Pharmacology Department, School of Medical Sciences, Health Campus, Universiti Sains Malaysia, Kubang Kerian, Kelantan, Malaysia for supplying the Malaysian Tualang Honey and Stingless Bee Propolis.

\section{REFERENCES}

Abd Rahim, Nour El Huda Mohamed, Farahidah Ku Zaifah, Norsidah Zulkifly, Ahmad Hafiz. Rheology of Malaysian Tualang honey. In: International Health Conference IIUM 2011, 7th-8th December 2011, Hotel Vistana, Kuantan, Pahang, Malaysia.

Ahn M, Kumazawa S, Usui Y, Nakamura J, Matsuka M, Zhu F, Nakayama, T. Antioxidant activity and constituents of propolis collected in various areas of China. Food Chemistry, 2007; 13831392.

Alvarez M, Burn T, Luo Y, Pirofski LA, Casadevall A. The outcome of Cryptococcus neoformans intracellular pathogenesis in human monocytes. BMC Microbio, 2009; 9: 51.

Arvouet-Grand A, Vennat B, Pourrat A, Legret P. Standardisation dun extrait de propolis identification des principaux constituants. J Pharm Belg, 1994; 49 (6): 462-468.

Bang LM, Buntting C, Molan P. The effect of dilution on the rate of hydrogen peroxide production in honey and its implications for wound healing. J Altern Complement Med, 2003; 9 (2): 267-273.
Bankova V, Solange De Castro, Maria Marcucci. Propolis: Recent advances in chemistry and plant origin. Apidologie Springer Verlag, 2000; 31 (1): 3-15.

Beretta G, Granata P, Ferrero M, Orioli M, Facino RM. Standardization of antioxidant properties of honey by a combination of spectrophotometric/fluorimetric assays and chemometrics. Anal Chim Acta, 2005; 533: 185-191.

Bertoncelj J, Doberšek U, Jamnik M, Golob T. Evaluation of the phenolic content, antioxidant activity and colour of Slovenian honey. Food Chemistry, 2007; 105 (2): 822-828.

Buchanan KL, and Murphy JW. What makes Cryptococcus neoformans a pathogen? Emerg Infect Dis, 1998; 4 (1): 71-83.

Burdock GA. Review of the biological properties and toxicity of bee propolis. Food Chem Toxicol, 1998; 36 (4): 347-363.

Campos FM, Couto JA, Figueiredo AR, Tóth IV, Rangel AOSS, Hogg TA. Cell membrane damage induced by phenolic acids on wine lactic acid bacteria. Int J Microbiol, 2009; 135(2): 144-51.

Clinical and Laboratory Standards Institute. Performance standards for antimicrobial susceptibility testing. Nineteenth informational supplement M100-S19. Wayne, PA: Clinical and Laboratory Standards Institute; 2009.

Dalben-Dota KF, Faria MG, Bruschi ML, Pelloso SM, LopesConsolaro ME, Svidzinski TI. Antifungal activity of propolis extract against yeasts isolated from vaginal exudates. J Altern Complement Med, 2010; 16 (3): 285-290

De Carvalho Duailibe SA, Goncalves AG, Mendes Ahid FJ. Effect of a propolis extract on Streptococcus mutans counts in vivo. J Appl Oral Sci, 2007; 15: 420-423.

DeMera J, Angert E. Comparison of the antimicrobial activity of honey produced by Tetragonisca angustula (Meliponinae) and Apis mellifera from different phytogeographic regions of Costa Rica. Apidologie, 2004; 35 (4): 411-417.

Estevinho L, Pereira AP, Moreira L, Dias LG, Pereira E. Antioxidant and antimicrobial effects of phenolic compounds extracts of Northeast Portugal honey. Food Chem Toxicol, 2008; 46 (12): 3774-3779.

Farnesi AP, Aquino-Ferreira R, De Jong D, Bastos JK, Soares AE. Effects of stingless bee and honey bee propolis on four species of bacteria. Genet Mol Res, 2009; 8 (2): 635-640.

Franchini RA, de Souza CF, Colombara R, Matos MA, Matos RC. Rapid determination of hydrogen peroxide using peroxidase immobilized on Amberlite IRA-743 and minerals in honey. J Agric Food Chem, 2007; 55 (17): 6885-6890.

George NM, Cutting KF. Antibacterial honey (Medihoney ${ }^{\mathrm{TM}}$ ): In vitro activity against clinical isolates of MRSA, VRE and other multiresistant gram-negative organisms including Pseudomonas aeruginosa. Wounds, 2007; 19: 231-236.

Heard TA. The role of stingless bees in crop pollination. Annu Rev of Entomol, 1999; 44: 183-206.

Hegazia AG, El Hadyb F, and Alla F. Chemical composition and antimicrobial activity of european propolis. Z Naturforsch, 2000; 55: 70-75.

Irish J, Carter DA, Shokohi T, Blair SE. Honey has an antifungal effect against Candida species. Med Mycol, 2006; 44: 289-291.

Jayanthi B, Kothai S. Evaluation of antioxidant and antimicrobial activity of stingless bee propolis (Tetragonula iridipennis) of Tamilnadu, India. Int J Pharm Pharm Sci, 2014; 6(8): 81-85.

Kačániová M, Melich M, Vladimíra K. The antimicrobial activity of honey and propolis against yeasts Candida species. Scientific Papers Animal Science and Biotechnologies, 2009; 42 (2): 167-173.

Khalil MD, Ibrahim S, Siti Amrah Alam, Nadia Ramli, Norzihana Mohamed Mahaneem, Bai'e Saringat, Gan Siew Hua. Content and antioxidant properties of processed honey (agromasi1/2) collected from different regions in Malaysia. Int J Pharm Pharm Sci, 2010; 4(3): 214-219.

Koc AN, Silici S, Ercal BD, Kasap F, Hormet-Oz HT, MavusBuldu H. Antifungal activity of Turkish honey against Candida spp. and Trichosporon spp: an in vitro evaluation. Med Mycol, 2009; 47 (7): $707-$ 712. 
Kourkoumpetis T, Manolakaki D, Velmahos G, Chang Y, Alam HB, De Moya M. Candida infection and colonization among non-trauma emergency surgery patients. Virulence, 2010; 1 (5): 359-366.

Kujumgiev A, Tsvetkova I, Serkedjieva Y, Bankova V, Christov R, and Popov S. Antibacterial, antifungal and antiviral activity of propolis from different geographic origins. J Ethnopharm, 1999; 64 (3): 235-240.

Kumazawa S, Hamasaka T, and Nakayama T. Antioxidant activity of propolis of of various geographic origins. Food Chemistry, 2004; 84 (3): 329-339.

Maria LE, Afonso SE, and Xesús F. Antifungal effect of lavender honey against Candida albicans, Candida krusei and Cryptococcus neoformans. J Food Sci Technol, 2011; 48 (5): 640-643.

Melliou E, Stratis E, Chinou I. Volatile constituents of propolis from various regions of greece-antimicrobial activity. Food Chemistry, 2007; 103 (2): 375-380.

Mirza SA, Phelan M, Rimland D, Graviss E, Hamill R, Brandt ME. The changing epidemiology of cryptococcosis: an update from population-based active surveillance in 2 large metropolitan areas. Clin Infect Dis, 2003; 36 (6): 789-794.

Mohamed M, Sirajudeen KN, Swamy M, Yaacob NS, Sulaiman SA. Studies on the antioxidant properties of Tualang honey of Malaysia. Afr J Tradit Complement Altern Med, 2010; 7 (1): 59-63.

Molan PC. Manuka honey as a medicine. Global Bioactives Summit; The University of Waikato. New Zealand (NZ): Waikato Honey Research Unit, 2001; 1-20.

Molan PC. The role of honey in the management of wounds. J Wound Care, 1999; 8 (8): 415-418.

Moniruzzaman M, Khalil M, Sulaiman S, Gan S. Advances in the analytical methods for determining the antioxidant properties of honey: A review. Afr J Tradit Complement Altern Med, 2012; 9 (1): 36-42.

Montero JC, Mori GG. Assessment of ion diffusion from a calcium hydroxidepropolis paste through dentin. Braz Oral Res, 2012; 26 (4): $318-322$

Moreira L, Dias LG, Pereira JA, Estevinho L. Antioxidant properties, total phenols and pollen analysis of propolis samples from Portugal. Food Chem Toxicol, 2008; 46 (11): 3482-3485.

Nucci M, Queiroz-Telles F, Tobón AM, Restrepo A, Colombo AL. Epidemiology of opportunistic fungal infections in Latin America. Clin Infect Dis, 2010; 51 (5): 561-570.

Oliveira AC, Shinobu CS, Longhini R, Franco SL, Svidzinzki TI. Antifungal activity of própolis extract against yeasts isolated from onychomycosis lesions. Mem Inst Oswaldo Cruz, 2006; 101(5): 493-497.

Ota C, Unterkircher C, Fantinato V, and Shimizu MT. Antifungal activity of propolis on different species of Candida. Mycoses, 2001; 44 (9-10): 375-8.

Pappas PG, Kauffman CA, Andes D, Benjamin DK, Calandra TF, Edwards JE. Clinical practice guidelines for the management of candidiasis: update by the Infectious Diseases Society of America. Clin Infect Dis, 2009; 48 (5): 503-535.

Rossi S. 2012. Australian Medicines Handbook [online]. Adelaide: $\mathrm{AMH}$.
Salmon TB, Evert BA, Song B, and Doetsch PW. Biological consequences of oxidative stress-induced DNA damage in Saccharomyces cerevisiae. Nucleic Acids Research, 2004; 32 (12): 3712-3723.

Sforcin JM, Bankova V. Propolis: is there a potential for the development of new drugs. J Ethnopharmacol, 2011; 133 (2): 253-260.

Shehu A, Mohd AKR, Aniza A, Salwani I. Antibacterial activity and antioxidant capacity of Malaysian tualang honey. International Journal of Science and Research, 2015; 4 (4): 1758-1762.

Shin GT, Yim H, Park J, Kim H. Membranous nephropathy associated with fluconazole treatment. Am J Kidney Dis, 2007; 49 (2): 318-322.

Silva BB, Rosalen PL, Cury JA, Ikegaki M, Souza VC, Esteves A, and Alencar SM. Chemical composition and botanical origin of red propolis, a new type of Brazilian propolis. Evid Based Complement Alternat Med, 2008; 5: 313-316.

Singleton VL, Orthofer R, Lamuela-Ravento RM. Analysis of total phenols and other oxidation substrates and antioxidants by means of Folin-Ciocalteu reagent. Methods in Enzymol, 1999; 299: 152-178.

Siqueira ABS, Gomes BS, Cambuim I, Maia R, Abreu S, Souza-Motta CMD, Queiroz LA, Porto, ALF. Trichophyton species susceptibility to green and red Propolis from Brazil. Letters in Applied Microbio, 2009; 48: 90-96.

Sobel JD. Vulvovaginal candidosis. Lancet, 2007; 369 (9577): 1961-1971.

Tan HT, Rahman RA, Gan SH, Halim AS, Hassan SA, Sulaiman SA. The antibacterial properties of Malaysian tualang honey against wound and enteric microorganisms in comparison to manuka honey. BMC Complement Altern Med, 2009; 9 (34): 1-8.

Usman $\mathrm{H}$, Abdulrahman FI, Ladan AH. Phytochemical and antimicrobial evaluation of tribulus terrestris 1. (zygophylaceae) growing in Nigeria. Res J Bio, 2007; 2 (3): 244 - 247.

Vollekova A, Kostalova D, Sochorova R. Isoquinoline Alkaloids from Mahonia aquifolium stem bark is active against Malassezia spp. Folia Microbiol, 2001; 46 (2): 107 - 111.

Wahdan HA. Causes of the antimicrobial activity of honey. Infection, 1998; 26 (1): 26-30.

Zhishen J, Mengcheng T, Jianming W. The determination of flavonoid contents in mulberry and their scavenging effects on superoxide radicals. Food Chemistry, 1999; 64: 555-559.

\section{How to cite this article:}

Shehu A, Ismail S, Rohin MAK, Harun A, Aziz AA, Haque M. Antifungal Properties of Malaysian Tualang Honey and Stingless Bee Propolis against Candida albicans and Cryptococcus neoformans. J App Pharm Sci, 2016; 6 (02): 044-050. 